\title{
Late Pleistocene sedimentation in the Western Mediterranean Sea: implications for productivity changes and climatic conditions in the catchment areas
}

\author{
Syee Weldeab ${ }^{\mathrm{a}, \mathrm{c}, *}$, Wolfgang Siebel ${ }^{\mathrm{a}}$, Rolf Wehausen ${ }^{\mathrm{b}}$, Kay-Christian Emeis ${ }^{\mathrm{c}}$, \\ Gerhard Schmiedl $^{\text {d }}$, Christoph Hemleben ${ }^{\text {a }}$ \\ a Institute for Geosciences, University of Tübingen, Tübingen, Germany \\ b Institute for Chemistry and Biology of the Marine Environment, University of Oldenburg, Oldenburg, Germany \\ c Institute for Baltic Sea Research Warnemünde, Rostock-Warnemünde, Germany \\ d Institute for Geophysics and Geology, University of Leipzig, Leipzig, Germany
}

Received 28 March 2002; received in revised form 15 June 2002; accepted 18 October 2002

\begin{abstract}
Sediment cores from the Western Mediterranean Sea (WMS) have been analyzed for their bulk element composition, $\delta^{18} \mathrm{O}$ values of planktic foraminiferal tests, and ${ }^{87} \mathrm{Sr} /{ }^{86} \mathrm{Sr}$ and ${ }^{143} \mathrm{Nd} /{ }^{144} \mathrm{Nd}$ ratios of their bulk lithogenic components. The investigated time interval comprises the last $215 \mathrm{kyr}$. Si/Al and Ti/Al ratios as well as radiogenic isotope compositions indicate changes in the provenance of the lithogenic components between glacial intervals and interglacial phases. Comparison with modern data indicates that detrital input from the northwestern and northeastern Sahara may have dominated during interglacial phases. In contrast, during glacial periods the accumulation rate of terrigenous sediment is high and changes in the sediment source areas are evident that may be related to changes in the prevailing atmospheric circulation over the basin and its source areas. A productivity reconstruction based on bio-mediated barium accumulation rates reveals increased surface productivity during glacial phases. Intervals time-equivalent to sapropel formation in the Eastern Mediterranean Sea (EMS) show no changes in surface productivity compared to the intervening intervals. Comparison of the productivity patterns between the WMS and EMS suggests a decoupling during Late Pleistocene sapropel formation and highlights the importance of more localized factors such as the freshwater drainage basin.
\end{abstract}

(C) 2002 Elsevier Science B.V. All rights reserved.

Keywords: Western Mediterranean Sea; biogenic and lithogenic sediments; $\mathrm{Sr}$ and $\mathrm{Nd}$ isotope; source areas; paleoproductivity

\footnotetext{
* Corresponding author. Present address: Fachbereich Geowissenschaften, Universität Bremen, P.O.Box 330440, 28334 Bremen, Germany. Tel.: +49-421-218-8911; Fax: +49-421-218-8916.

E-mail address: sweldeab@uni-bremen.de (S. Weldeab).
}

\section{Introduction}

The Mediterranean Sea is a semi-enclosed basin surrounded by catchment areas characterized by various climate regimes. Therefore, it is very sensitive to tectonically and climatically induced environmental changes. This is witnessed by the 
Messinian evaporites (Ryan, 1973) and the cyclic deposition of sapropels (Kullenberg, 1952; Olausson, 1961), which are organic-rich layers sandwiched between hemipelagic, carbonate-rich, sediments deposited under oxic conditions. Sapropel deposition can be traced back to at least 5.3 million years ago (Lourens et al., 1996; Emeis et al., 2000a) and has attracted the interest of paleoceanographers since its discovery in 1947 during the Swedish Deep-Sea Expedition (Kullenberg, 1952). An excellent review by Cramp and O'Sullivan (1999) provides an overview of the results and models for sapropel formation. Sapropels occur during insolation maxima in the northern hemisphere (Rossignol-Strick, 1983; Rossignol-Strick, 1985; Hilgen, 1991a, 1991b; Lourens et al., 1996). These times are coupled with increased seasonal contrasts and intensified runoff resulting in both hydrographic and productivity changes in the Mediterranean Sea (Rossignol-Strick et al., 1982; Rohling, 1994). However, the exact sources of freshwater causing a positive water balance, the mode of nutrient delivery to the photic zone, and the question of whether the productivity increase precedes the cutoff of deep water ventilation or not, are still under debate (Cramp and O'Sullivan, 1999; Emeis et al., 2000a,b). Most sapropel investigations have been concentrated in the Eastern Mediterranean Sea (EMS). This is because in the EMS the Late Pleistocene sapropels/sapropelic layers occur throughout the whole area (Kidd et al., 1978; Emeis and Sakamoto, 1998) in water depths up to $125 \mathrm{~m}$ (Cramp et al., 1988; Perissoratis and Piper, 1992). In the Western Mediterranean Sea (WMS), however, Late Pleistocene sapropels, as defined by Kidd et al. (1978), were only detected in the Tyrrhenian Sea (Emeis et al., 1991). Recently Murat (1999) described Late Pleistocene organic-rich layers (ORL) in the WMS and correlated these layers with the eastern basin sapropels. Nevertheless, the absence of unequivocal/pronounced Late Pleistocene sapropels in the WMS (as they are present in the EMS) probably points to different climate evolutions in the Western and Eastern Mediterranean regions during the Late Pleistocene, leading to different hydrographic conditions at times of Northern Hemisphere insolation max- ima. Despite this contrast, there are hardly any paleoceanographic investigations focusing on comparisons of both the western and eastern basins. Furthermore, chemical and/or radiogenic isotope investigations of the terrigenous source of the core material in the WMS are not available to date. Such results can provide valuable information about the paleoclimatic conditions in the catchment/source areas.

For this study, a sediment core from the WMS spanning the marine isotope stages (MIS) 1 to upper part of MIS 7.3 has been sub-sampled at high resolution and analyzed for bulk-element geochemistry, total organic carbon (TOC) content, and $\delta^{18} \mathrm{O}$ of planktic foraminiferal tests. On a parallel core from the same site, which was sub-sampled at lower resolution, analyses of ${ }^{87} \mathrm{Sr} /{ }^{86} \mathrm{Sr}$ and ${ }^{143} \mathrm{Nd} /{ }^{144} \mathrm{Nd}$ ratios have been conducted on the bulk lithogenic components. While the $\mathrm{Nd}$ isotope composition is little affected by grain-size differences of the sediment fractions and is also resistant to changes during weathering, transport, and winnowing processes (Goldstein et al., 1984; Walter et al., 2000), the Sr isotope composition can be influenced by grain-sized sorting as well as sediment diagenesis (Dasch, 1969; Walter et al., 2000). Nevertheless, the $\mathrm{Sr}$ and Nd isotope compositions provide unique information about the paleoenvironment such as changes in detrital sediment sources and prevailing atmospheric circulation (via changing provenance) (Grousset et al., 1998).

Accumulation of biogenic-mediated barium was also used as proxy for changes in surface productivity through time, and comparison is made with results from time-equivalent intervals in the EMS in order to derive information about the linking processes between the western and eastern basins. Barium and/or barite $\left(\mathrm{BaSO}_{4}\right)$ has been proven as a robust proxy for paleoproductivity reconstructions (Dehairs et al., 1980; Bishop, 1988; Dymond et al., 1992; Francois et al., 1995; Gingele et al., 1999 and citations therein). Difficulty arises, however, when anoxia prevails and sulfate reduction - and subsequently Ba remobilization - occurs (Brumsack and Gieskes, 1983; Van Os et al., 1994; Breymann et al., 1992; Gingele et al., 1999). Preservation of $\mathrm{Ba}$ upon deposition is also a fur- 
ther constraint in the application of the $\mathrm{Ba}$ paleoproductivity reconstruction (McManus et al., 1998; Schenau et al., 2001). The exact mechanism of the tight correlation between enhanced surface water productivity and high barite contents in the underlying water column and sea floor is not yet clearly deciphered. Bernstein et al. (1992) suggested the dissolution of acantharian-derived celestite $\left(\mathrm{SrSO}_{4}\right)$ as a major source of $\mathrm{Ba}$ and sulfate. Bertram and Cowen (1997) reported biotic origin of barite crystals with specific morphology. A widely accepted hypothesis, however, is that barite formation occurs within microenvironments during decay of labile organic matter (Dehairs et al., 1980; Bishop, 1988; Dymond et al., 1992). In the EMS, the applicability of $\mathrm{Ba}$ for surface water paleoproductivity reconstruction during sapropel formation has been demonstrated by Thomson et al. (1995) and Van Santvoort et al. (1996).

\section{Materials and methods}

The investigated sediment cores (SL87 and KL66) and multi-corer sediments were recovered during RV Meteor expedition M40/4 in spring 1998 at the same site in the WMS $\left(38^{\circ} 59.34 \mathrm{~N}\right.$, $04^{\circ} 01.40 \mathrm{E}$; water depth $1900 \mathrm{~m}$ ) (Fig. 1). The cored sediment consists of foraminiferal-bearing/ pteropod-bearing, pale brown/greenish gray mud and pteropod-bearing, yellowish brown foraminiferal mud and is moderately to strongly bioturbated. Separate sub-samples were taken from SL87 for inorganic geochemistry, TOC content, calcium carbonate, and foraminiferal stable isotope analysis by $10-\mathrm{ml}$ syringes at a sample spacing between 2 and $4 \mathrm{~cm}$. Sub-sampling in KL66 was in lower resolution at sample spacing between 10 and $15 \mathrm{~cm}$; these samples were used for radiogenic isotope analysis. After determining volume and wet weight, the samples for element analysis

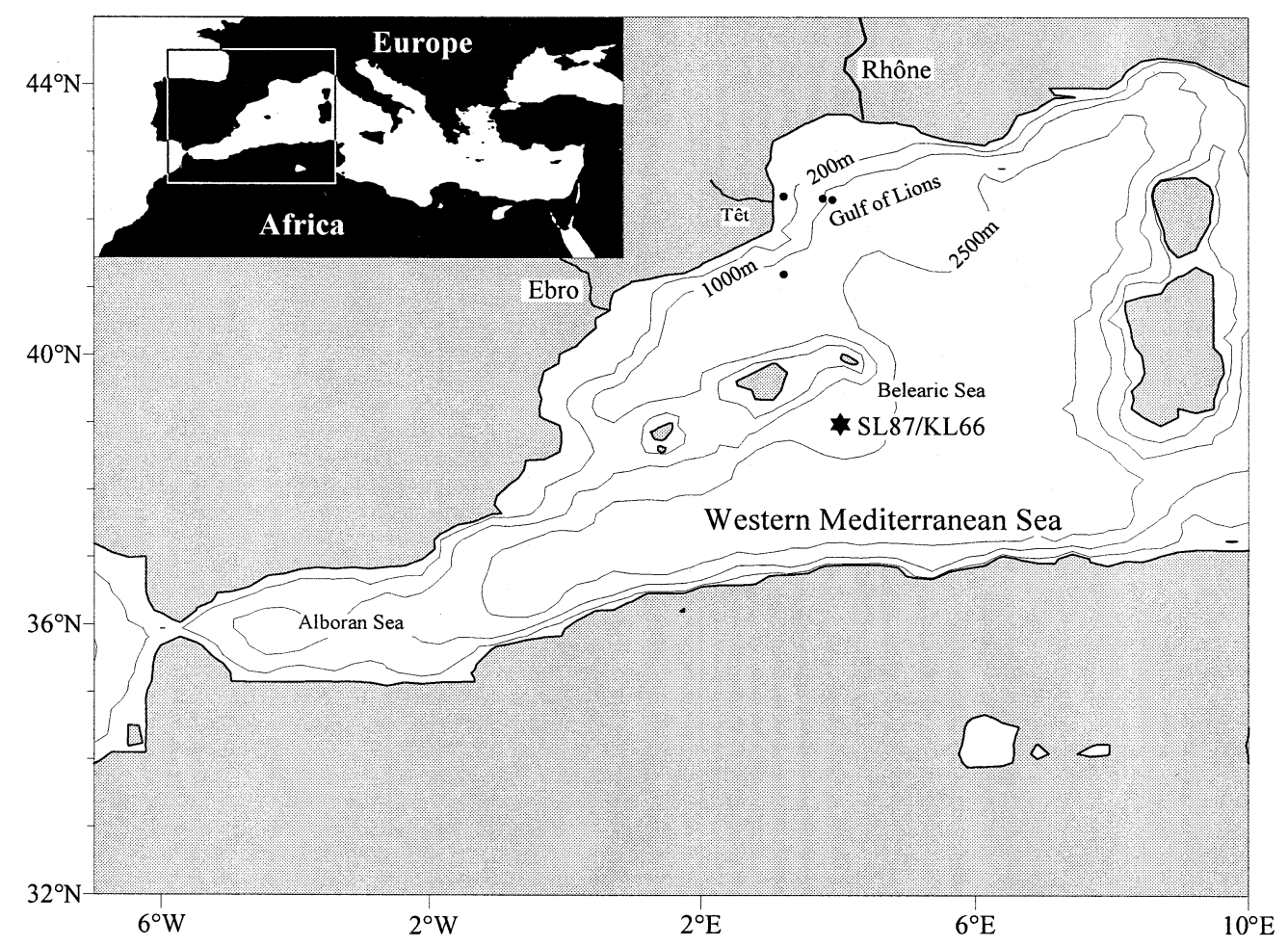

Fig. 1. Bathymetric map of the Western Mediterranean Sea showing sample locations (asterisk indicates the cores; dots the surface samples). 
were dried at $105^{\circ} \mathrm{C}$ for $48 \mathrm{~h}$. Dry bulk density was calculated as ratio of dry weight and wet volume.

Stable oxygen isotope ratios of calcareous foraminiferal tests from KL66 were analyzed to establish the stratigraphic framework. Between 10 and 17 tests of the planktic foraminifer Globigerina bulloides were picked from the size fraction $>250 \mu \mathrm{m}$ and were ultrasonically cleaned. The samples were analyzed using an automated carbonate device linked to a Finnigan MAT 251 mass spectrometer at the Leibniz-Laboratory for Radiometric Dating and Stable Isotope Research, University of Kiel, Germany. External reproducibility for stable oxygen isotopes was $<0.03 \%$. The isotope stratigraphy for SL87 used here was measured on Globigerinoides ruber and is from Weldeab et al. (in press). The age model for the cores (SL87 and KL66) is based on a graphic correlation of the $\delta^{18} \mathrm{O}$ curves with the SPECMAP isotope curve of Martinson et al. (1987) using the software package 'AnalySeries' (Paillard et al., 1996). Between the fix points of SPECMAP events, ages were calculated by linear interpolation.

Total carbon (TC) analysis was carried out by combustion at $1200^{\circ} \mathrm{C}$, followed by coulometric determination of the evolved $\mathrm{CO}_{2}(\mathrm{C}-\mathrm{S}$ Analyzer). TOC determination was conducted by combustion, followed by coulometric determination of the evolved $\mathrm{CO}_{2}$ of sub-samples $(\mathrm{C}-\mathrm{S}$ Analyzer) that were soaked in $10 \% \mathrm{HCl}$ overnight and dried to constant weight. Carbonate contents were obtained as difference between TC and TOC and multiplied by stoichiometric factor (8.33). The precision determined on replicate sub-samples was $\pm 2 \mathrm{wt} \%$ for carbonate contents and $0.1 \mathrm{wt} \%$ for TOC contents.

Major and trace elements were determined by $\mathrm{X}$-ray fluorescence spectrometry (Philips PW 2400) using the method described by Wehausen and Brumsack (2000). $600 \mathrm{mg}$ powdered and homogenized sediment was mixed with di-lithiumtetraborate, pre-oxidized at $500^{\circ} \mathrm{C}$, and fused to glass beads in Pt crucibles. The accuracy and precision were checked by co-analyses of international standards and replicate analyses of sediment samples, respectively. The analytical accuracy was within $1-8 \%$ of certified values. Precision was better than $5 \%$ for all elements presented in this work. In order to use the barium content as an indicator for paleoproductivity, the biogenic barium $\left(\mathrm{Ba}_{\mathrm{bio}}\right)$ and detrital barium fraction have to be distinguished. Based on the Ba content of surface sediments and present oligotrophic conditions of the Mediterranean Sea we estimate the terrigenous $\mathrm{Ba}$ contents to be around $140 \mathrm{ppm}$. Assuming that Al in the sediments exclusively originates from aluminosilicate, we consider a detrital ratio of $\mathrm{Ba} / \mathrm{Al}=0.002$ reasonable. Accumulation rates of biogenic $\mathrm{Ba}$, TOC, calcium carbonate, and terrigenous sediment are obtained as product of sedimentation rate, bulk dry density, and fraction of the components. The component of the terrigenous sediments is defined as the difference the bulk sediment and the sum of carbonate and TOC contents $\left[100-\left(\mathrm{CaCO}_{3} \quad \mathrm{wt} \%+\mathrm{TOC}\right.\right.$ $w t \%)]$.

Analyses of the ${ }^{87} \mathrm{Sr} /{ }^{86} \mathrm{Sr}$ and ${ }^{143} \mathrm{Nd} /{ }^{144} \mathrm{Nd} \mathrm{ra}-$ tios on the lithogenic/terrigenous fraction were conducted on a Finnigan MAT 262 mass spectrometer using static collection mode at the Institute of Geosciences, University of Tübingen. Details of the analytical procedure are described by Weldeab et al. (2002). In order to remove the carbonate fractions, $500 \mathrm{mg}$ of powdered and homogenized sediment was leached with $10 \mathrm{ml}$ acetic acid $(5 \mathrm{M})$ at room temperature for $12 \mathrm{~h}$. The detrital residue was rinsed four times with deionized water and centrifuged. A 50-mg portion of the dried residue was spiked with a mixed ${ }^{149} \mathrm{Sm}:{ }^{150} \mathrm{Nd}$ spike prior to digestion in HF. The digested samples were dried and dissolved in $6 \mathrm{~N}$ $\mathrm{HCl}$, dried and then redissolved in $2.5 \mathrm{~N} \mathrm{HCl}$. Analyses of NBS-SRM 987 and Nd Ames-Metal measurements while this study was being conducted yielded ${ }^{87} \mathrm{Sr} /{ }^{86} \mathrm{Sr}=0.710266 \pm 09$ and ${ }^{143} \mathrm{Nd} /{ }^{144} \mathrm{Nd}=0.512124 \pm 09, \quad$ respectively. The ${ }^{87} \mathrm{Sr} /{ }^{86} \mathrm{Sr}$ ratios are normalized to ${ }^{86} \mathrm{Sr} /$ ${ }^{88} \mathrm{Sr}=0.1194$ and the ${ }^{143} \mathrm{Nd} /{ }^{144} \mathrm{Nd}$ ratios to ${ }^{146} \mathrm{Nd} /{ }^{144} \mathrm{Nd}=0.7219$. Measurement of the La Jolla $\mathrm{Nd}$ standard yielded $0.511835 \pm 12$. Results of blank measurements are $100-150 \mathrm{pg}$ for $\mathrm{Nd}$ and $100-120 \mathrm{pg}$ for $\mathrm{Sr}$. The ${ }^{143} \mathrm{Nd} /{ }^{144} \mathrm{Nd}$ ratios are 


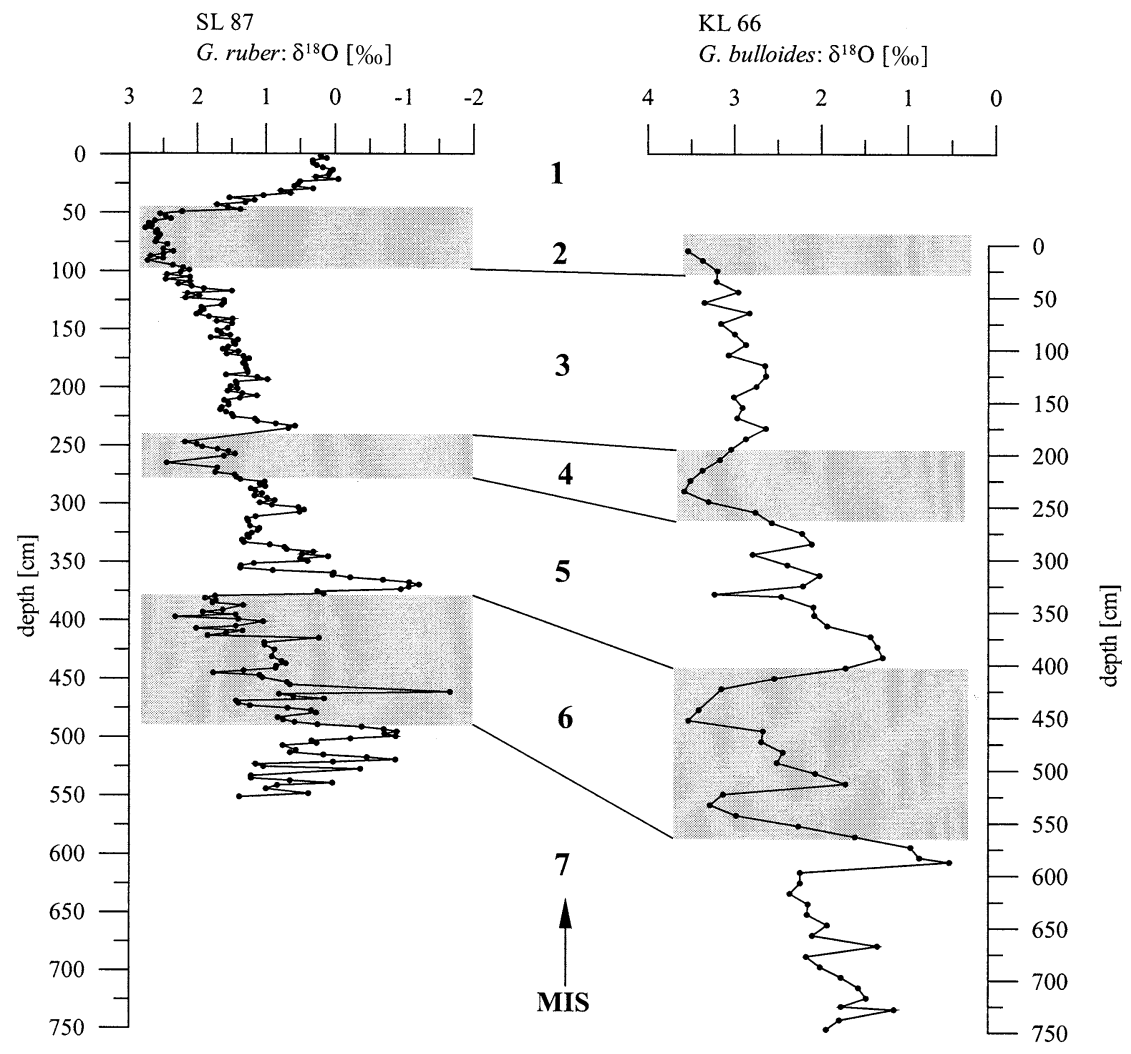

Fig. 2. Oxygen isotope stratigraphy and correlation of the investigated cores. Gray areas and numbers indicate the glacial sections and marine isotope stages (MIS), respectively. Stratigraphy for SL87 is from Weldeab et al. (in press).

expressed as $\varepsilon_{\mathrm{Nd}}(0)$, where $\varepsilon_{\mathrm{Nd}}(0)$ are isotopic values normalized to the 'chondritic uniform reservoir' value $(0.512636)$ of Jacobson and Wasserburg (1980).

The carbonate-free fractions of the marine sediments are referred to here as terrigenous/lithogenic components. Authigenic minerals such as clay minerals, anhydrite, and $\mathrm{Mn}$ and $\mathrm{Fe}$ oxides are difficult to distinguish from detrital minerals. Given that the terrigenous flux is relatively high, the fraction of authigenic minerals is probably very low. Organic carbon content does not exceed 0.4 $\mathrm{wt} \%$. The biogenic barite content, as recalculated from 'biogenic' barium, accounts for $<0.02 \mathrm{wt} \%$. Biogenic opal is of minor importance in the sediments due to the relatively oligotrophic conditions and dissolution. Thus, consideration of biogenic opal has been neglected.

\section{Results}

\subsection{Isotope stratigraphy}

The $\delta^{18} \mathrm{O}$ records of cores SL87 and KL66 show a range between 2.75 and $-1.75 \%$ (Globigerinoides ruber var. white) and 3.75 and $0.3 \%$ (Globigerina bulloides), respectively (Fig. 2). The variations reflect the general pattern of the interglacial-glacial changes. The amplitudes are, however, higher than those from the open ocean as shown, for instance, by Martinson et al. (1987). Correlation with the SPECMAP curve (Martinson et al., 1987) reveals that core SL87 extends back to MIS 7.3. From the oxygen isotope stratigraphy, it is evident that the upper part of core KL66 (comprising the Holocene and part of MIS 2) is absent probably due to disturbance during 
G. ruber (white): $\delta^{18} \mathrm{O}[\%]$

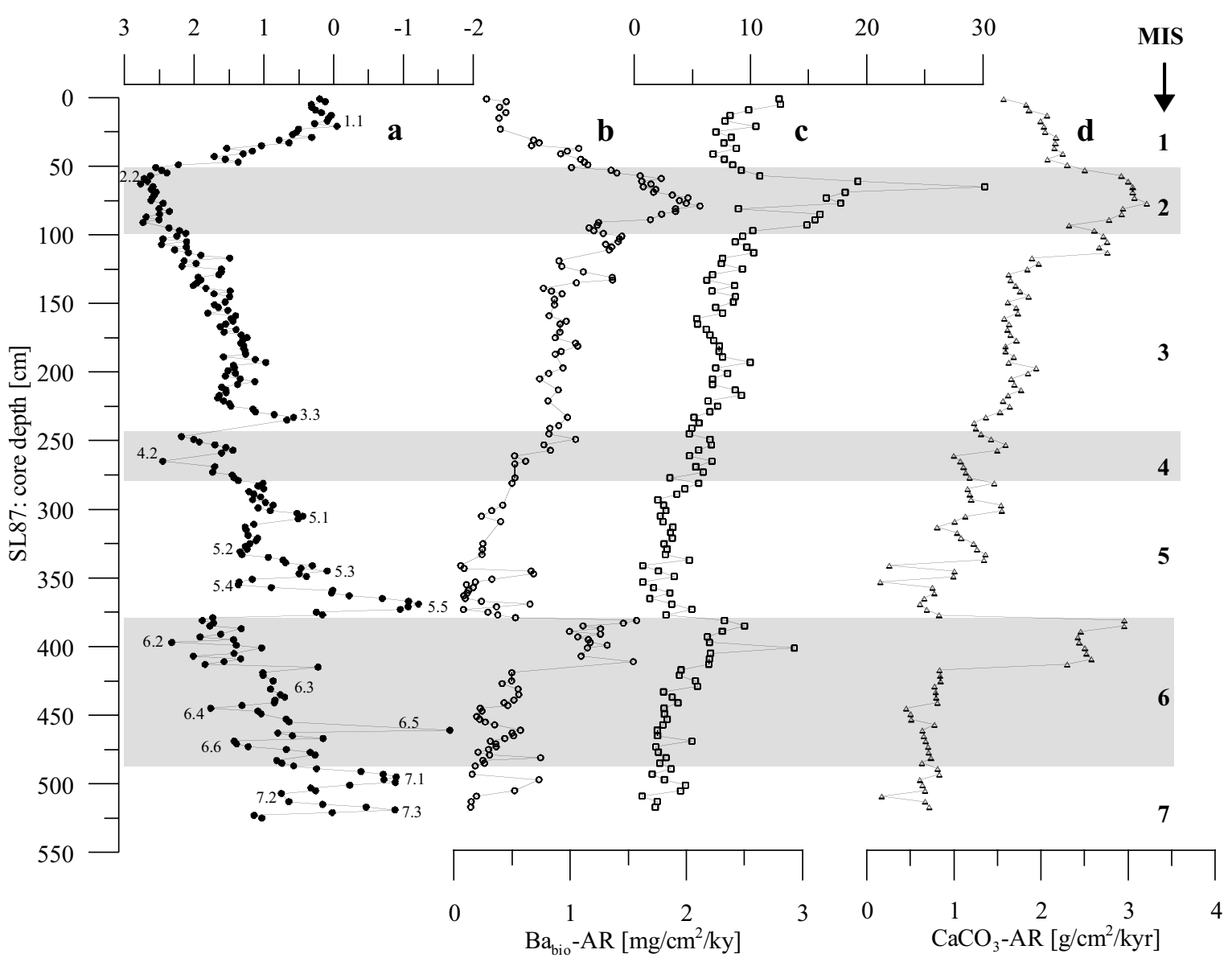

Fig. 3. (a) Stratigraphy, (b) Biogenic Ba accumulation rate (Babio-AR), (c) Total organic carbon accumulation rate (TOC-AR), and (d) Calcium carbonate accumulation rate $\left(\mathrm{CaCO}_{3}-\mathrm{AR}\right)$ of core SL87. Grey areas and numbers indicate glacial sections and marine isotope stages (MIS), respectively. Stratigraphy for SL87 is from Weldeab et al. (in press).

recovery. In order to consider Holocene sediment for the radiogenic isotope analyses, sediment of one of the multi-cores was included. The heaviest $\delta^{18} \mathrm{O}$ values are measured on samples from MIS 2; MIS 5.5 and 7.1 show pronounced light values. In SL87, the lightest $\delta^{18} \mathrm{O}$ value occurs at MIS 6.5 , but this is a one point peak. The linear sedimentation rate (LSR) varies more than four-fold between 1.6 and $7.8 \mathrm{~cm} / \mathrm{kyr}$ in SL87, as shown by Weldeab et al. (in press). Highest LSR values are documented at MIS $2(7.8 \mathrm{~cm} / \mathrm{kyr})$ and MIS 6.2 $(5.7 \mathrm{~cm} / \mathrm{kyr})$.

\subsection{Biogenic sediments: $B a_{b i o}-, T O C-$, and $\mathrm{CaCO}_{3}$-accumulation rates}

In Fig. $3 b$ the biogenic $\mathrm{Ba}$ accumulation rate ( $\left.\mathrm{Ba}_{\mathrm{bio}}-\mathrm{AR}\right)$ is shown. The $\mathrm{Ba}_{\mathrm{bio}}-\mathrm{AR}$ displays distinct glacial-interglacial cyclicity. Interglacial intervals (MIS 1 and 5) show $\mathrm{Ba}_{\mathrm{bio}}$-AR values that are generally less than $0.5 \mathrm{mg} / \mathrm{cm}^{2} / \mathrm{kyr}$. MIS 3 is characterized by $\mathrm{Ba}_{\text {bio }}-\mathrm{AR}$ values between 0.8 and $1 \mathrm{mg} / \mathrm{cm}^{2} / \mathrm{kyr}$. Glacial periods (mainly MIS 2 and 6.2) show the highest values varying between 1.3 and $2 \mathrm{mg} / \mathrm{cm}^{2} / \mathrm{kyr}$. In MIS 4 and the lower 


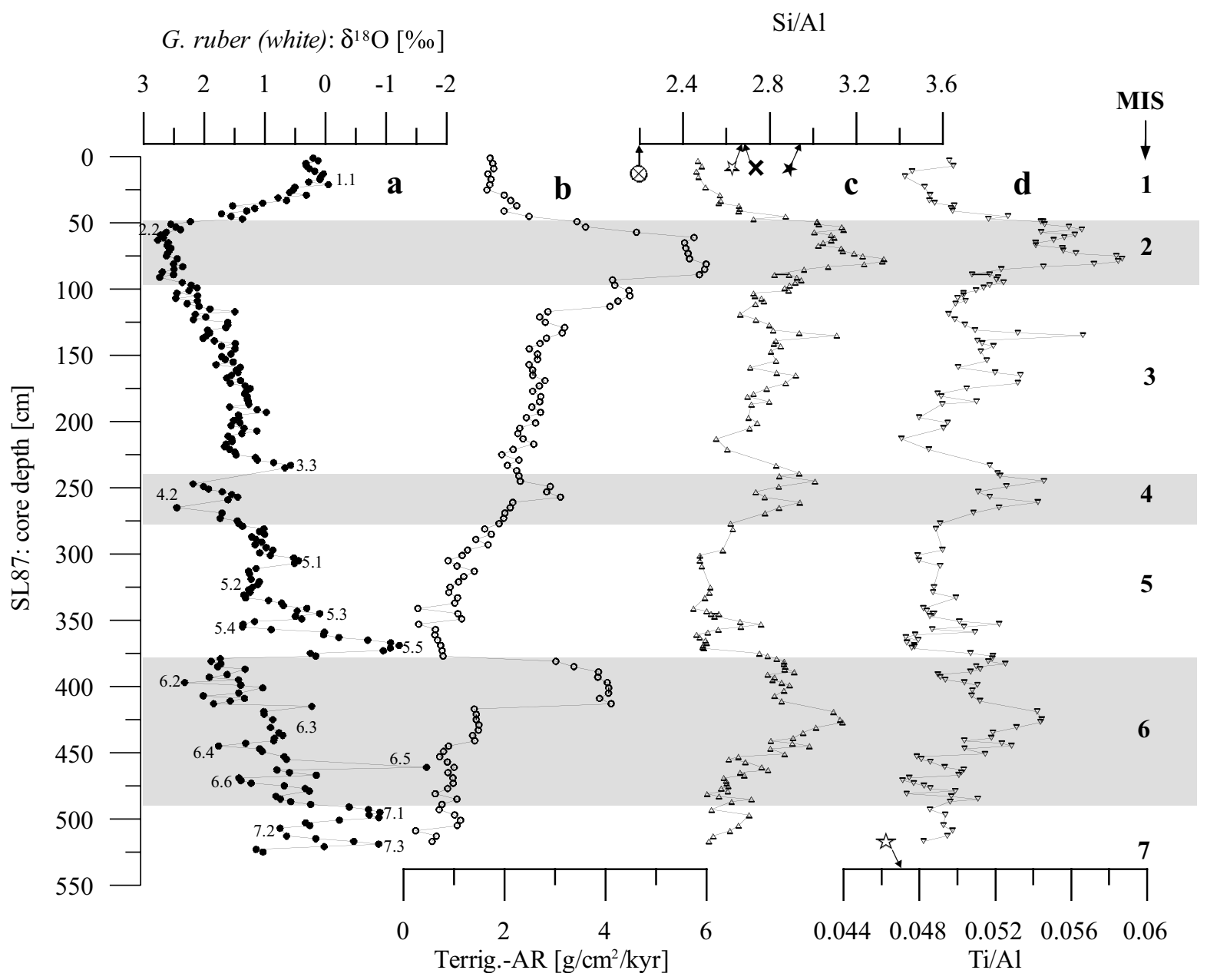

Fig. 4. (a) Stratigraphy, (b) accumulation rate of terrigenous sediments (Terrig.-AR), (c) Si/Al ratios, and (d) Ti/Al ratios. In (c) average $\mathrm{Si} / \mathrm{Al}$ ratios of modern Saharan dust from different regions heading towards the WMS are indicated (data from Bergametti et al., 1989): $\otimes$ northeastern Sahara (Tunisia and western Libya), $\times$ northwestern Sahara (Morocco and western Algeria), and $\star$ southern Sahara and Sahelian region. Average $\mathrm{Si} / \mathrm{Al}$ and Ti/Al ratios of surface sediments dominated by river-derived matter (mainly Rhône and Têt) are shown as is in (c) and (d).

part of MIS 6, the increase of $\mathrm{Ba}_{\text {bio }}-\mathrm{AR}$ is not pronounced.

TOC-accumulation rates (TOC-AR) vary between 2 and $12\left(\mathrm{mg} / \mathrm{c}^{2} / \mathrm{kyr}\right)$ during interglacial periods, and between 4 and $20\left(\mathrm{mg} / \mathrm{cm}^{2} / \mathrm{kyr}\right)$ during glacial intervals (Fig. 3c). The highest values of TOC-AR occur during MIS 2 and 6.2. Greater accumulation rates of calcium carbonate $\left(\mathrm{CaCO}_{3}-\mathrm{AR}\right)$ occur in glacial age sediments of MIS 2 and 6.2 (Fig. 3d). The average increase of $\mathrm{CaCO}_{3}$ - $\mathrm{AR}$ in these stages is two- to fourfold in comparison to interglacial average values (e.g. MIS 5).

\subsection{Accumulation rate of terrigenous sediment, Sil Al and TilAl ratios}

The variation of accumulation of rates of terrigenous sediment (Terrig.-AR), Si/Al and Ti/Al ratios vs. core depth (SL87) are displayed in Fig. 4. A pronounced increase of Terrig.-AR is observed during glacial phases (MIS 2, 4, and 

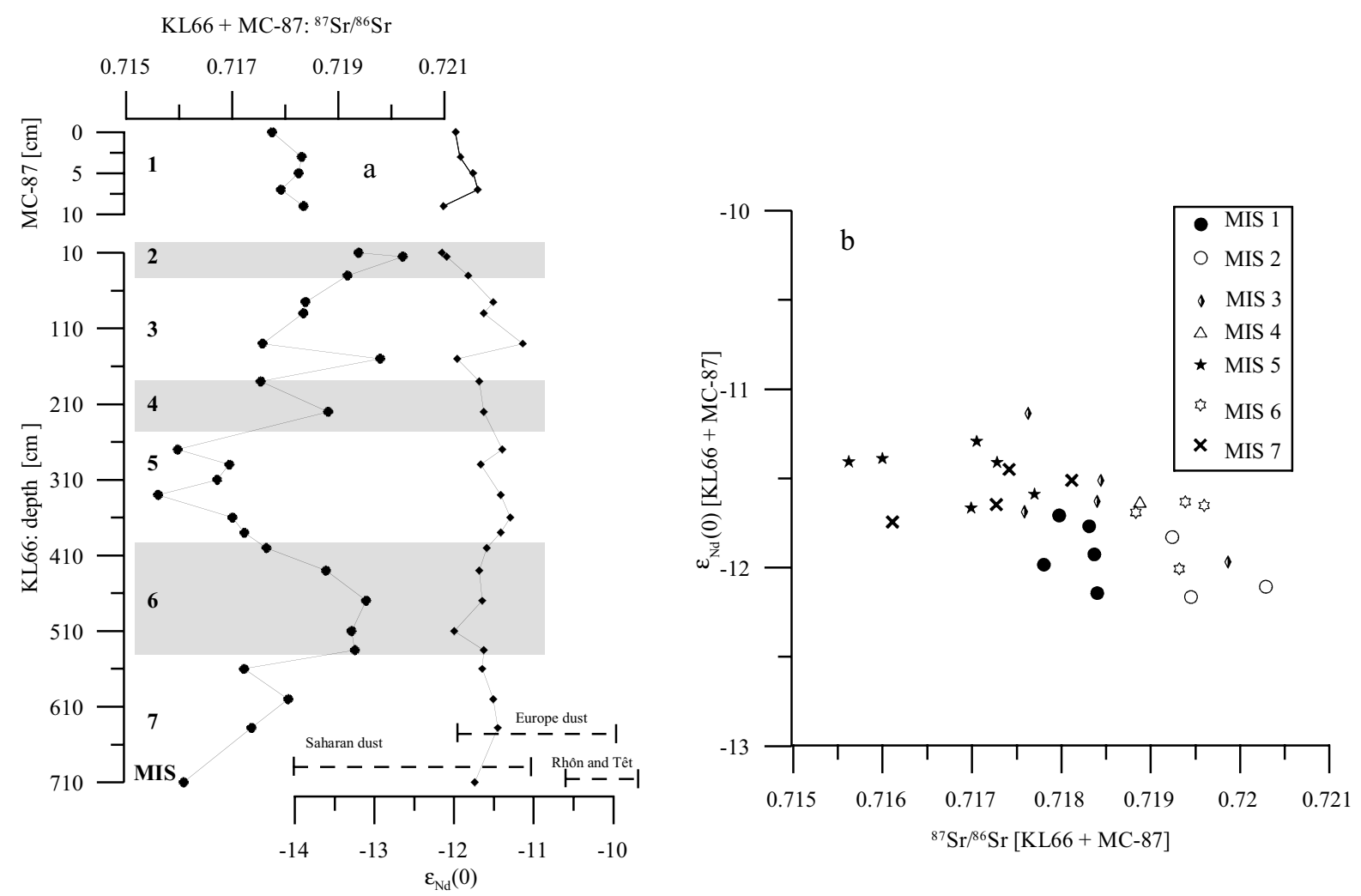

Fig. 5. (a) ${ }^{87} \mathrm{Sr} /{ }^{86} \mathrm{Sr}$ and ${ }^{143} \mathrm{Nd} /{ }^{144} \mathrm{Nd}$ ratios, expressed as $\varepsilon_{\mathrm{Nd}}(0)$, vs. depth in KL66 and MC-87. The ranges of $\varepsilon_{\mathrm{Nd}}(0)$ values of Saharan dust over the WMS (Grousset et al., 1998), riverine sediments entering the WMS, and European dust (Henry et al., 1994) is shown. (b) ${ }^{87} \mathrm{Sr} /{ }^{86} \mathrm{Sr}$ vs. ${ }^{143} \mathrm{Nd} /{ }^{144} \mathrm{Nd}$ ratios, expressed as $\varepsilon_{\mathrm{Nd}}(0)$, of core KL66 and MC-87.

6.2) varying between 3 and $6 \mathrm{~g} / \mathrm{cm}^{2} / \mathrm{kyr}$. In contrast, interglacial periods (MIS 1 and 3) and the lower part of MIS 6 are characterized by low Terrig.-AR showing variation between 1 and 1.7 $\mathrm{g} / \mathrm{cm}^{2} / \mathrm{kyr}$. MIS 3 shows intermediate values around $2.3 \mathrm{~g} / \mathrm{cm}^{2} / \mathrm{kyr}$.

The $\mathrm{Si} / \mathrm{Al}$ and $\mathrm{Ti} / \mathrm{Al}$ ratios show pronounced interglacial-glacial changes together with high ratios during glacial periods ( $\mathrm{Si} / \mathrm{Al}$ up to 3.3 and $\mathrm{Ti} /$ Al up to 0.059) and low ratios during interglacial periods ( $\mathrm{Si} / \mathrm{Al}$ up to 2.5 and $\mathrm{Ti} / \mathrm{Al}$ up to 0.048 ). The increase is most pronounced during MIS 2 and 6.2 (Fig. 4c,d).

\section{4. $\mathrm{Sr}$ and Nd isotopic composition of bulk lithogenic fraction}

The down-core variation of ${ }^{87} \mathrm{Sr} /{ }^{86} \mathrm{Sr}$ and the ${ }^{143} \mathrm{Nd} /{ }^{144} \mathrm{Nd}$ ratio (expressed as $\varepsilon_{\mathrm{Nd}}(0)$ ) of the lithogenic component, as well as the relation of $\varepsilon_{\mathrm{Nd}}(0)$ to the ${ }^{87} \mathrm{Sr} /{ }^{86} \mathrm{Sr}$ ratios, is shown in Fig. 5a,b. The analysis was conducted on sediments of core KL66 (lacking the Holocene section and the upper part of MIS 2) and the multi-core sediments that span the Holocene (Fig. 5a). The down-core variability of the $\varepsilon_{\mathrm{Nd}}(0)$ values is quite uniform ranging between -12.2 and -11.1 . The ${ }^{87} \mathrm{Sr} /{ }^{86} \mathrm{Sr}$ ratios display a somewhat more pronounced oscillation that may be related to glacial-interglacial cycles. MIS 6, 4 , and 2 (glacials) are characterized by higher ${ }^{87} \mathrm{Sr} /{ }^{86} \mathrm{Sr}$ ratios showing maximum values of $0.7195,0.7197$, and 0.7202, respectively (Fig. $5 a, b)$. Generally, interglacial intervals show intermediate ratios between 0.7175 and 0.7184 . However, intervals MIS 7.1 and 5.5 have low ${ }^{87} \mathrm{Sr} /{ }^{86} \mathrm{Sr}$ ratios varying between 0.7155 and 0.7160 . 


\section{Discussion and interpretation}

\subsection{Productivity changes}

The $\mathrm{Ba}_{\mathrm{bio}}$-AR shows that the Balearic Sea was marked by low surface water productivity during interglacial stages MIS 7, 5, and 1 (Fig. 3b). During glacial phases and MIS 3, productivity was higher than during interglacials. Highest productivity increase occurs during MIS 2 and 6.2. The above described productivity variation is also reflected in the TOC-AR (Fig. 3c). The increase of TOC-AR, however, is less pronounced, especially during MIS 6.2 in comparison to the changes indicated by the $\mathrm{Ba}_{\text {bio }}-\mathrm{AR}$ (Fig. 3b,c). The lower TOC-AR may be related to oxic hemipelagic conditions in which organic matter arriving at the sea floor is degraded to its refractory fraction (Stein, 1990). $\mathrm{CaCO}_{3}$-AR is highest during glacial periods and lowest during interglacial phases. Dilution, dissolution, and/or a change in carbonate production could be responsible for the rise and decline of the carbonate fraction (Van Os et al., 1994). Sediment redistribution may have also played an important role in the enhanced $\mathrm{CaCO}_{3}-\mathrm{AR}$ (Ruddiman, 1997). This is likely for the glacial phases where shelf area is exposed to erosion and redistribution due to sea-level lowering. In this study, the variations in $\mathrm{CaCO}_{3}-\mathrm{AR}$ seem to be primarily related to carbonate productivity and sediment redistribution during glacial phases (e.g. MIS 2 and 6.2).

As stated above, interglacial periods, and especially the intervals comprising MIS 7.1, 6.5, 5.5, and 5.3, appear to represent times of low surface water productivity. In the EMS, these time intervals correspond to sapropel S7, S6, S5, and S4, respectively (e.g. Calvert and Fontugne, 2001; Weldeab et al., in press). Compared to the EMS, the surface productivity in the WMS is very low. In core SL87 for instance, the $\mathrm{Ba}_{\text {bio }^{-}}$ AR maxima are $0.8 \mathrm{mg} / \mathrm{cm}^{2} / \mathrm{kyr}$ in MIS $5.5,0.4$ $\mathrm{mg} / \mathrm{cm}^{2} / \mathrm{kyr}$ in MIS 6.5 , and $0.5 \mathrm{mg} / \mathrm{cm}^{2} / \mathrm{kyr}$ in MIS 7.1. In contrast, in core SL71 from the EMS (southwest of Crete), the time-equivalent intervals show $\mathrm{Ba}_{\text {bio }}-\mathrm{AR}$ of $12.1 \mathrm{mg} / \mathrm{cm}^{2} / \mathrm{kyr}$ (MIS $5.5 \sim \mathrm{S} 5$ ), $3.5 \mathrm{mg} / \mathrm{cm}^{2} / \mathrm{kyr}$ (MIS 6.5 S6), and $8 \mathrm{mg} / \mathrm{cm}^{2} / \mathrm{kyr}$ (MIS $7.1 \sim \mathrm{S} 7$ ) (Weldeab et al., in press). No indication of pronounced productivity increase is observed in the Early Holocene in sediment corresponding to sapropel S1 in the EMS. In the Alboran Sea, the presence of an ORL has been reported. However, the deposition time of this layer has been estimated between 10.7 and 14.5 kyr BP (Murat, 1999), which is diachronous to the S1 in the EMS that starts at $9 \mathrm{kyr} \mathrm{BP}$ and lasts at least to $6 \mathrm{kyr}$ BP (Mercone et al., 2000). Murat (1999) and Capotondi and Vigliotti (1999) investigated an ODP core from the Balearic Sea at Site 975. At this site Capotondi and Vigliotti (1999) also identified ORLs, showing TOC contents between 0.8 and $1.5 \mathrm{wt} \%$, and they correlated these ORLs with sapropels S5-S9 of the EMS. The location of ODP Site 975 is situated southwest of our core location and has a water depth of $2416 \mathrm{~m}$. The findings of Capotondi and Vigliotti (1999) indicate that slightly enhanced surface water productivity prevailed here at times of sapropel formation in the EMS. A high sedimentation rate and, thus, improved TOC preservation rate at the ODP Site may account for the differences in TOC contents between the two adjacent sites. This seems likely because the ODP site is more exposed to deep water currents and hence receives more suspended matter from the northern WMS. However, the $\mathrm{Ba}_{\text {bio }}-\mathrm{AR}$, which is more reliable for paleoproductivity reconstruction (e.g. Dymond et al., 1992), does not corroborate the conclusion that surface productivity was higher during the above mentioned time intervals.

\subsection{Terrigenous sedimentation}

To characterize the temporal variability of terrigenous sedimentation and to reconstruct provenance changes, the terrigenous accumulation rate, element ratios ( $\mathrm{Si} / \mathrm{Al}$ and $\mathrm{Ti} / \mathrm{Al}$ ), and the composition of $\mathrm{Sr}$ and $\mathrm{Nd}$ isotopes of the lithogenic fraction will be discussed. In this context, it is necessary first to introduce the main contemporary catchment areas of the Balearic Sea and their geochemical characteristics.

\subsubsection{Catchment areas and their geochemical characteristics}

The main catchments of the Balearic Sea, espe- 
cially impacting our core location, are the drainage areas of the Rhône and Ebro rivers (Fig. 1), smaller rivers in the northern borderland, and the North African desert belt in the south. The drainage basins of the Rhône and Ebro rivers cover a variety of geologic units, with rainfall ranging between 500 and $1000 \mathrm{~mm} / \mathrm{yr}$ (Martin and Milliman, 1997). Sediment loads of the two rivers and the resulting sedimentation rates in their estuaries and on the continental shelf are very high (Martin et al., 1989; Wegrzynek et al., 1997; Zuo et al., 1997; Guerzoni et al., 1999). Towards deeper parts of the basin, however, sedimentation rates rapidly decrease (Zuo et al., 1997). Martin et al. (1989) estimated a total riverine input of $9 \times 10^{6}$ $\mathrm{t} / \mathrm{yr}$ into the northwestern Mediterranean Sea. However, only $1 \times 10^{6} \mathrm{t} / \mathrm{yr}$ of the total riverine input reaches the open ocean of the WMS (Martin et al., 1989). Geochemical investigations of the riverine suspended matter of the Rhône and Ebro rivers are not available. Wegrzynek et al. (1997) provided individual particle analysis of Rhône suspended matter, sediments from the Gulf of Lions, and atmospheric inputs using electron $\mathrm{X}$-ray microanalysis. Although their results give valuable information on the abundance of certain grain sizes and associated oxide compositions of some major elements, the results are, however, less useful for distinction of bulk geochemical composition between the riverine and atmospheric sources. In our study, bulk geochemical analyses of five surface sediments from the Gulf of Lions are included (Fig. 1). These surface samples are assumed to reflect mainly the composition of Rhône and Têt suspended matter due to the high accumulation rates of sediments from this source (Zuo et al., 1997). The average element/ $\mathrm{Al}$ ratios of the bulk geochemistry of $\mathrm{Si}$ and $\mathrm{Ti}$ are: $\mathrm{Si} / \mathrm{Al}=2.7$ and $\mathrm{Ti} / \mathrm{Al}=0.047$. Another, better, possibility of characterizing sediments and their provenance is the analysis of the radiogenic isotope composition, such as $\varepsilon_{\mathrm{Nd}}(0)$ and ${ }^{87} \mathrm{Sr} /{ }^{86} \mathrm{Sr}$. This approach has been successfully used in the EMS (Krom et al., 1999a; Krom et al., 1999b; Freydier et al., 2001; Weldeab et al., 2002a,b). For the northwestern Mediterranean Sea, Nd isotope analyses on riverine matter, atmospheric in- puts, and trapped sediment samples have been conducted (Frost et al., 1986; Grousset et al., 1990; Henry et al., 1994). Henry et al. (1994) provided the most comprehensive study and characterized the different sediment sources of the WMS based on their ${ }^{143} \mathrm{Nd} /{ }^{144} \mathrm{Nd}$ compositions. They obtained for Saharan dust an average value of $\varepsilon_{\mathrm{Nd}}(0)=-13.0 \pm 1.0$, for riverine particles (mainly from the Têt and Rhône rivers) an average value of $\varepsilon_{\mathrm{Nd}}(0)=-10.1 \pm 0.5$, and for atmospheric inputs of European origin a value of $\varepsilon_{\mathrm{Nd}}(0)=-11.2 \pm 1.0$. In agreement with the study of Frost et al. (1986), Henry et al. (1994) reported a value of $\varepsilon_{\mathrm{Nd}}(0)=-9.6 \pm 0.2$ from the sediment water interface of the river Rhône.

An important source of terrigenous matter to the WMS is the Sahara Desert. The Sahara is one of the largest regional sources of atmospheric dust, accounting for most of the terrigenous fraction of marine sediment in the tropical/subtropical Atlantic Ocean and the Mediterranean Sea (for comprehensive reviews see Rea, 1994; Prospero, 1996; Guerzoni et al., 1999; Goudie and Middleton, 2001). According to Loye-Pilot et al. (1986); Martin et al. (1989); Guerzoni et al. (1999), the Saharan dust inputs to the open western Mediterranean Sea constitute more than $80 \%\left(\sim 4 \times 10^{6}\right.$ $\mathrm{t} / \mathrm{yr}$ ) of the total terrigenous (riverine+eolian) flux. Within the Sahara, the major source areas for dust transported towards the western and central Mediterranean have been identified. These areas are geochemically discernible from each other and are related to specific meteorological conditions (Bergametti et al., 1989; D’Almeide, 1989; Dulac et al., 1992; Molinaroli, 1996). ${ }^{87} \mathrm{Sr} /{ }^{86} \mathrm{Sr}$ and ${ }^{143} \mathrm{Nd} /{ }^{144} \mathrm{Nd}\left(\varepsilon_{\mathrm{Nd}}(0)\right)$ investigations of Saharan dust heading towards the WMS show characteristic signatures varying between 0.712 and 0.724 and $\varepsilon_{\mathrm{Nd}}(0)=-10.9$ to -14.6 , respectively (Grousset et al., 1988; Grousset et al., 1990; Grousset et al., 1992; Henry et al., 1994; Grousset et al., 1998). Riverine contribution to the open WMS from areas bordering the southern shores of the western Mediterranean is negligible due to the narrow drainage basin and due to sparse rainfall, which is less than $500 \mathrm{~mm} / \mathrm{yr}$ and mainly restricted to coastal areas (Martin and Milliman, 1997). 


\subsubsection{Temporal variation of the detrital fraction}

Bearing in mind the present dominant sources for detrital matter and their geochemical and radiogenic isotope characteristics, temporal variations of the bulk geochemistry as well as $\mathrm{Sr}$ and $\mathrm{Nd}$ isotopic composition of the bulk lithogenic fraction will be discussed with regard to climatecoupled changes of atmospheric circulation and vegetative cover over the source areas.

As mentioned in Section 3 and depicted in Fig. $4 \mathrm{c}, \mathrm{d}$, the $\mathrm{Si} / \mathrm{Al}$ and $\mathrm{Ti} / \mathrm{Al}$ ratios are highest during glacial phases, especially during MIS 2 and 6 (average of $\mathrm{Si} / \mathrm{Al}=3.10$ and $\mathrm{Ti} / \mathrm{Al}=0.055$ ) and lowest during interglacial phases (average of $\mathrm{Si} /$ $\mathrm{Al}=2.55$ and $\mathrm{Ti} / \mathrm{Al}=0.05$ ). A pronounced glacial-interglacial pattern is also displayed by Terr.-AR being high during glacials and low during interglacials.

The radiogenic isotope distribution patterns reveal shifts in the importance of different provenance. Glacials, such as MIS 2 and 6, are dominated by detrital matter that is characterized by more radiogenic ${ }^{87} \mathrm{Sr} /{ }^{86} \mathrm{Sr}$ ratios. $\varepsilon_{\mathrm{Nd}}(0)$ values, however, do not show any convincing variability.

The observed variation in element/Al ratio could be caused either by an increase or decrease of contribution of certain clay minerals (e.g. kaolinite vs. smectite) or varying quartz and titaniumbearing heavy minerals. While the variation of kaolinite/smectite contents can be explained by changes in provenance as shown in the EMS (Foucault and Mèlières, 2000), contents of high quartz and Ti bearing minerals could be also controlled by wind speed. High wind speed may have caused mobilization of coarser weather-resistant minerals such as quartz, titanomagnetite, rutile, and ilmenite from distant areas (Wehausen and Brumsack, 2000; Moreno et al., 2001).

Combined geochemical investigations and trajectory reconstructions of Saharan dust (deduced from satellite images) heading toward the WMS indicate three productive dust sources in North Africa (Bergametti et al., 1989; Chiapello et al., 1997; Moulin et al., 1997). According to Bergametti et al. (1989), dust from Morocco and western Algeria is characterized by a mean value of $\mathrm{Si} /$ $\mathrm{Al}=2.7(n=15)$, dust from eastern Algeria, Tunisia and western Libya by an average value of $\mathrm{Si} /$
$\mathrm{Al}=2.2(n=17)$, and dust from areas of southern Sahara and the Sahelian zone ('South of $30^{\circ} \mathrm{N}$ ') are marked by mean values of $\mathrm{Si} / \mathrm{Al}=2.9(n=12)$. The predominance of one of the three dust sources is controlled by the position of the Inter-Tropical Convergence Zone (ITCZ), which determines the position of the subtropical anticyclones (Azores and Libyan ones). The anticyclone center, in turn, determines the southward extent of the incursion of cold polar air masses (Bergametti et al., 1987). Thus, for instance, the enhanced contribution of dust from 'South of $30^{\circ} \mathrm{N}$ ' to the WMS is associated with high/low pressure configurations generated by the southernmost position of the ITCZ during winter. This configuration causes a more southerly position of the anticyclone center.

The Late Pleistocene variability of lithogenic sediment delivery to the WMS can be reconstructed from the present different dust sources in the southern catchment area, their geochemical characteristics, and related atmospheric circulation (e.g. Bergametti et al., 1989). The isotope signatures of lithogenic sediments during glacials indicate a prevalence of detrital matter marked by more radiogenic ${ }^{87} \mathrm{Sr} /{ }^{86} \mathrm{Sr}$ ratios and high $\mathrm{Si} / \mathrm{Al}$ ratios as shown in Fig. 6. In this context, the question arises whether the observed changes in the terrigenous composition during glacial phases were related to changes in the quantitative input from the northern catchment areas. The glacial eustatic sea-level lowering was up to $130 \mathrm{~m}$ relative to the present day (i.e. Fleming et al., 1998). As a consequence, shelf areas would have been exposed to erosion and, thus, input of detrital matter to the basins may have been increased. Sediments of the northern riverine matter, however, are characterized by more radiogenic values (between $\varepsilon_{\mathrm{Nd}}(0)=-9.6$ and $\varepsilon_{\mathrm{Nd}}(0)=-10.1 \pm 0.5$ ) as reported by Frost et al. (1986) and Henry et al. (1994), and lower Si/Al and Ti/Al ratios as shown from surface sediments of the Gulf of Lions in this study. Assuming that the presented surface sediment data are representative for the riverine sediments, it is not likely that the observed temporal lithogenic variations are mainly controlled by dominance of sediment input from the northern catchment area. However, change of 


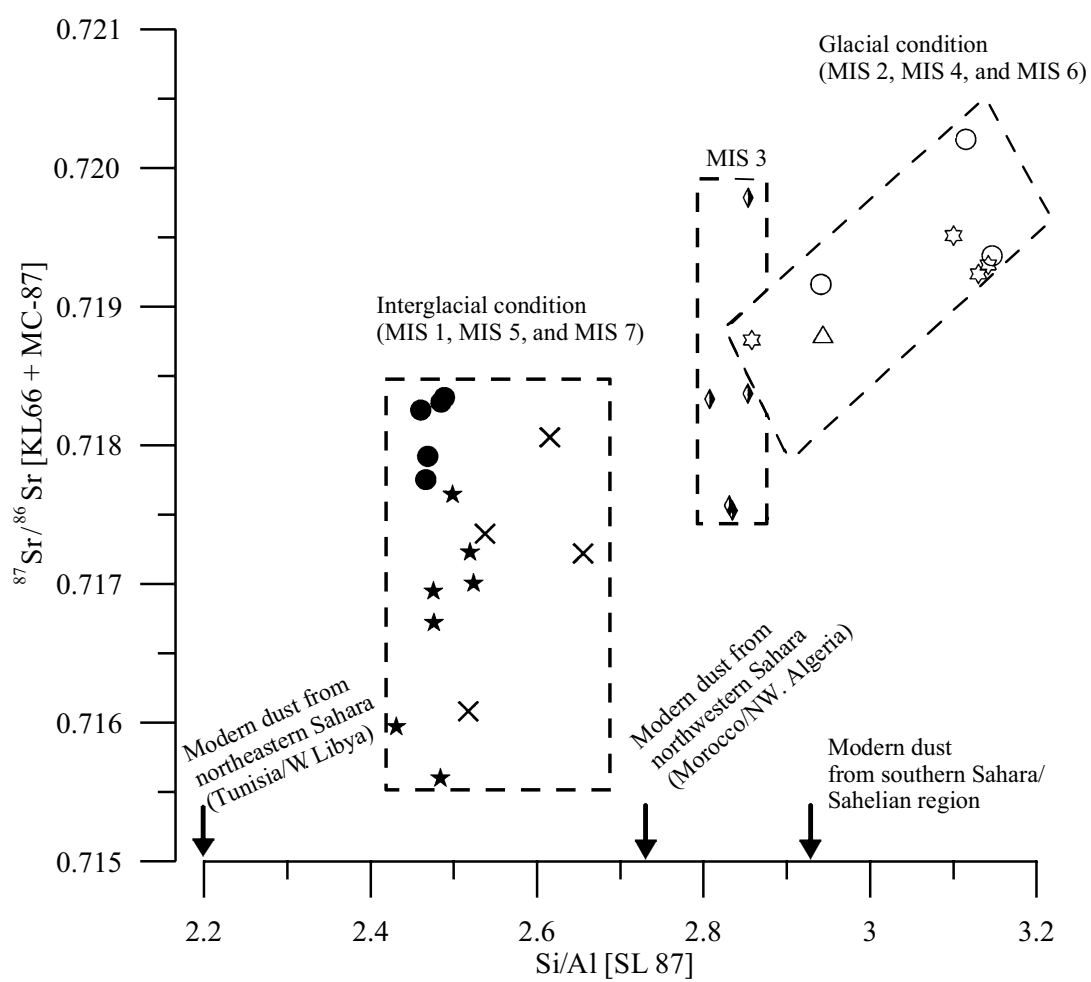

Fig. $6.87 \mathrm{Sr} /{ }^{86} \mathrm{Sr}$ vs. Si/Al ratios of cores SL87 and KL66/MC-87 (for legend see Fig. 5b). Scatter range of the data during glacial and interglacial conditions is shown. Arrows on axis of abscissae indicate average position of Si/Al ratios (data from Bergametti et al., 1989) of different sources from the Saharan and Sahelian region.

the catchment areas of the northern rivers and change in the chemical compositions would result in inadequate assessment of the riverine inputs. A further constraint is also the lack of data from suspended matter of the Ebro River.

Comparison of the element/Al ratios and the $\mathrm{Sr}$ isotope signatures of the Saharan dust from regions 'South of $30^{\circ} \mathrm{N}^{\prime}$ (southern Sahara and Sahelian region) and those of the glacial sediments argues for predominance of the southern sources of terrigenous matter at glacial intervals. Closer inspection, however, reveals that sediment inputs with $\mathrm{Si} / \mathrm{Al}$ and $\mathrm{Ti} / \mathrm{Al}$ ratio greater than that of southern sources identified by Bergametti et al. (1987) must also have been important at these periods. Grain-size dependent geochemistry alone is not likely to explain this observation. Since the $\varepsilon_{\mathrm{Nd}}(0)$ values, which are less grain-size dependent (Goldstein et al., 1984; Walter et al., 2000), also show signatures that are quite uniform and prob- ably represent a mixture of less radiogenic sediments of southern source (Grousset et al., 1998) and a sediment source with more radiogenic $\varepsilon_{\mathrm{Nd}}(0)$ values. Based on the data available, we are not able to identify the latter. At present, the relative amount of sediment input from the southern Sahara and Sahelian region to the WMS is low and occurs in winter when the ITCZ reaches its southernmost position (Bergametti et al., 1987; Dulac et al., 1992). During glacial phases, when the ITCZ occupied a more southerly average position and higher aridity and/ or high wind speeds prevailed (e.g. Matthewson et al., 1995), the frequency and intensity of dust export to the WMS from the southern Sahara and Sahelian regions could have intensified. Similarly, for the North Atlantic Ocean, evidence of intensified northeasterly and easterly wind and/or high aridity has been reported (Pokras and Mix, 1985; Hooghiemstra and Agwu, 1988; Balsam et al., 
1995; Matthewson et al., 1995; Ruddiman, 1997; Martinez et al., 1999; Yarinick et al., 2000).

Interglacial (MIS 1 and 5) compositions of element/Al ratios vary between $\mathrm{Si} / \mathrm{Al}=2.6-2.47$ and $\mathrm{Ti} / \mathrm{Al}=0.05-0.047$. According to Bergametti et al. (1989), these Si/Al ratios argue for dusts originating from Morocco/western Algeria and Tunisia/ western Libya. At present the frequency and intensity of dusts from these areas heading toward the WMS predominate (Dulac et al., 1992, Bergametti et al., 1987). This dominance is reflected in modern and interglacial sediments such as MIS 5 as shown in this study (Fig. 4c,d). Subsequently the moderate ${ }^{87} \mathrm{Sr} /{ }^{86} \mathrm{Sr}$ ratios and $\varepsilon_{\mathrm{Nd}}(0)$ values may be interpreted to characterize sediments showing a dominance of dusts from Morocco/ western Algeria and Tunisia/western Libya. During interglacials there are intervals showing least radiogenic ${ }^{87} \mathrm{Sr} /{ }^{86} \mathrm{Sr}$ ratios (Figs. 5 and 6). Although the stratigraphy in KL66 is not very precise because of the coarser sampling intervals, one may speculate that the lower ${ }^{87} \mathrm{Sr} /{ }^{86} \mathrm{Sr}$ ratios coincide with short-term humid phases in the southern source areas (Lèzine and Casanova, 1991). This result may point to reduced input of dust from southern source areas due to humid climate and denser vegetation cover. In the EMS, the reduction of Saharan dust due to humid climate and, subsequently, reduced dust mobilization has been clearly documented by means of $\mathrm{Sr}$ and $\mathrm{Nd}$ isotope composition of the lithogenic fraction during sapropel formation (Krom et al., 1999b; Freydier et al., 2001; Weldeab et al., 2002b). By analogy, and based on our observation, this could be also assumed for dust sources of the WMS.

As shown in this study (Figs. 4-6), lithogenic variations in the WMS mainly co-vary with glacial-interglacial phases. However, lithogenic variations in the EMS vary with the precession cycles. Thereby, the Saharan dust input is reduced at time of precession minima in the northern hemisphere, i.e. intensification of African monsoon (Wehausen and Brumsack, 2000; Calvert and Fontugne, 2001; Weldeab et al., 2002b). This difference is surprising since the Sahara is a common (eolian) source area for both the WMS and the EMS. Furthermore, it has been shown that a monsoon-driven increase of humidity prevailed and northward extension of vegetation cover occurred simultaneously in the western, central, eastern parts of North Africa during northern hemisphere insolation maxima (Causse et al., 1989; Pachur and Kröpelin, 1989; Lèzine and Casanova, 1991). This implies that all dust sources for the WMS, as well as for the EMS, were influenced by denser vegetation cover as the result of humid conditions. Thus, additional factors should be considered for the discrepancy in Saharan dust input between both the western and eastern basins. It has been demonstrated that the presence of different cyclones is responsible for the Saharan dusts heading toward the WMS and the EMS (Bergametti et al., 1989; Dulac et al., 1992; Moulin et al., 1997). As a possible explanation for the discrepancy in dust input, it could be speculated that cyclones responsible for Saharan dust transport toward the EMS were notably weakened during the humid periods in North Africa. To substantiate this hypothesis, however, further studies are required. Nevertheless, this study in comparison with previous works in the EMS (for instance Calvert and Fontugne, 2001, Weldeab et al., 2002b, in press) shows that the WMS and the EMS respond differently to the insolation climatic induced changes in their source areas.

\section{Summary and conclusions}

This investigation is based on material from two adjacent cores (SL87 and KL66) from the Balearic Sea in the WMS. Core SL87 was subsampled in high resolution (mostly between 2 and $4 \mathrm{~cm}$ ) and analyses have been conducted for element composition of the bulk sediment as well as TOC and carbonate contents. The stratigraphy of SL87 was established in a previous study by Weldeab et al. (in press). Sampling resolution is coarser in KL66 varying between 10 and $15 \mathrm{~cm}$. Oxygen isotope stratigraphy of KL66 reveals that the Holocene section and upper part of MIS 2 is absent. In order to consider the Holocene, an upper interval from multi-corer material was included in the investigation. In both KL66 and the 
multi-corer core ${ }^{87} \mathrm{Sr} /{ }^{86} \mathrm{Sr}$ and ${ }^{143} \mathrm{Nd} /{ }^{144} \mathrm{Nd}$ of the bulk lithogenic fraction has been measured.

Based on the $\mathrm{Ba}_{\text {bio }}-\mathrm{AR}$, variations in surface water productivity have been reconstructed. Productivity in this part of the basin is generally low throughout the Late Pleistocene. The $\mathrm{Ba}_{\mathrm{bio}}-\mathrm{AR}$ reveals, however, that during glacial phases such as MIS 2 and 6.2 surface productivity was enhanced. Furthermore, sediment intervals that correspond to times of sapropel formation in the EMS show no increases in surface productivity. This result may indicate environmental decoupling of the two basins during the formation of the Late Pleistocene sapropels in the EMS.

Variability of terrigenous input is reconstructed on the basis of Terrig.-AR, bulk element/Al ratios, and $\mathrm{Sr}$ and $\mathrm{Nd}$ isotope composition of the lithogenic fraction. During glacial periods Terrig. $\mathrm{AR}$ is high and dust originating from the southern Sahara/Sahelian region and sediment source that could not clearly identified may have been dominating (Fig. 6). Enhanced sediment input from shelf areas due to sea-level lowering may also have been important during the glacial phases. The enhanced contribution from the southern region can be attributed to a more southerly average position of the ITCZ and different subtropical high/low pressure configurations. The element/Al ratios and isotope signatures during interglacial phases are similar to that of modern surface sediment implying comparable conditions.

\section{Acknowledgements}

We thank the captain and crew of RV Meteor (cruise 40/4) for their help and assistance. Dr. H. Schulz (Institute for Baltic Sea Research) and Dr. U. Struck (Institute for Baltic Sea Research, now at the University of Munich) are cordially thanked for their support during the sub-sampling visits of S.W. at Warnemünde. We also thank E. Reitter for the $\mathrm{Sr}$ and $\mathrm{Nd}$ isotope analyses. Thoughtful and constructive reviews were provided by Dr. J. Gleason and Dr. D.K. Rea. This work was funded by grants of the Deutsche Forschungsgemeinschaft to K.-C.E. (Em37/8) and
Ch.H. (He 697/28). The data discussed in this study are available at the Pangaea data base (www.pangaea.de)

\section{References}

Balsam, W.L., Otto-Bliesner, B.L., Deaton, B.C., 1995. Modern and Last Glacial Maximum eolian sedimentation patterns in the Atlantic Ocean interpreted from sediments iron oxide content. Paleoceanography 10, 493-507.

Bergametti, G., Gomes, L., Remoudaki, E., Debois, M., Martin, D., Buat-Menard, P., 1989. Present transport and deposition patterns of African dusts to the North-Western Mediterranean. In: Leinen, M., Sarnthein, M. (Eds.), Paleoclimatology and Paleometeorology: Modern and Past Patterns of Global Atmospheric Transport. Mathematical and Physical Sciences. Kluwer Academic Publishers, Dordrecht, pp. 227-252.

Bernstein, R.E., Byrne, R.H., Betzer, P.R., Greco, A.M., 1992. Morphologies and transformations of celetite in seawater; The role of acantharians in strontium and barium geochemistry. Geochim. Cosmochim. Acta 56, 3273-3279.

Bishop, J.K.B., 1988. The barite-opal-organic carbon associations in oceanic particulate matter. Nature 332, 341-343.

Bertram, M., Cowen, J.P., 1997. Morphological and compositional evidence for biotic precipitation of marine barite. J. Mar. Res. 55, 577-593.

Breymann von, M., Emeis, K.-C., Suess, E., 1992. Water depth and diagenetic constraints on the use of barium as a palaeoproductivity indicator. In: Summerhayes, C.P., Prell, W.L., Emeis, K.-C. (Eds.), Upwelling Systems: Evolution since the Early Miocene. Geological Society Special Publication, Blackwell, Oxford, pp. 29-46.

Brumsack, J.H., Gieskes, J.M., 1983. Interstitial water tracemetal chemistry of laminated sediments from the Gulf of California, Mexico. Mar. Chem. 14, 89-106.

Calvert, S.E., Fontugne, M.R., 2001. On the Late PleistoceneHolocene sapropel record of climatic and oceanographic variability in the eastern Mediterranean. Paleoceanography 16, 78-94.

Capotondi, L., Vigliotti, L., 1999. Magnetic and microfaunal characterization of Late Quaternary sediments from the Western Mediterranean: influences about sapropel formation and paleoceanographic implication. In: Zahn, R., Comas, M.C., Klaus, A. (Eds.), Proceedings of the Ocean Drilling Program, Scientific Results. Ocean Drilling Project, College station, TX, pp. 505-517.

Causse, C., Coque, R., Fontes, J.-C., Gasse, F., Ben Quezdou, H., Zouari, K., 1989. Two high levels of continental waters in the southern Tunisian chots at about 90 and $150 \mathrm{ka}$. Geology 17, 922-925.

Chiapello, I., Bergametti, G., Chatenet, B., 1997. Origin of African dust transported over the northeastern tropical Atlantic. J. Geophys. Res. 102, 13701-13709.

Cramp, A., Collins, M., West, R., 1988. Late Pleistocene-Ho- 
locene sedimentation in the NW Aegean Sea: A palaeoclimatic palaeoceanographic reconstruction. Palaeogeogr. Palaeoclimatol. Palaeoecol. 68, 61-77.

Cramp, A., O'Sullivan, G., 1999. Neogene sapropels in the Mediterranean: a review. Mar. Geol. 153, 11-28.

Dasch, E.J., 1969. Strontium isotopes in weathering profiles, deep-sea sediments, and sedimentary rocks. Geochim. Cosmochim. Acta 33, 1521-1552.

D’Almeide, G.A., 1989. Desert aerosol: Characteristics and effects on Climate. In: Leinen, M., Sarnthein, M. (Eds.), Paleoclimatology and Paleometeorology: Modern and Past Patterns of Global Atmospheric Transport. Mathematical and Physical Sciences. Kluwer, Dordrecht, pp. 311-358.

Dehairs, F., Chesselet, R., Jedwab, J., 1980. Discrete suspended particles of barite and barium cycle in the open ocean. Earth Planet. Sci. Lett., 528-550.

Dulac, F., Tarnè, D., Bergametti, G., Burat-Ménard, P., Desbois, M., 1992. Assessment of the African aiborne dust mass over the western Mediterranean Sea using Meteosat data. J. Geophys. Res. 97, 2489-2506.

Dymond, J., Suess, E., Lyle, M., 1992. Barium in deep-sea sediment: a geochemical proxy for paleoproductivity. Paleoceanography 7, 163-181.

Emeis, K.-C., Camerlenghi, A., McKennzie, J.A., Rio, D., Sprovieri, R., 1991. The occurrence and significance of Pleistocene and Upper Pliocene sapropels in the Tyrrhenian Sea. Mar. Geol. 100, 155-182.

Emeis, K.-C., Sakamoto, T., 1998. The sapropel theme of Leg 160. Proc. Ocean Drilling Prog. Sci. Res. 160, 29-36.

Emeis, K.-C., Sakamoto, T., Wehausen, R., Brumsack, H.-J., 2000a. The sapropel record of the eastern Mediterranean Sea - results of Ocean Drilling Program Leg 160. Palaeogeogr. Palaeoclimatol. Palaeoecol. 158, 371-395.

Emeis, K.-C., Struck, U., Schulz, H.-M., Rosenberg, R., Bernosconi, S., Erlenkeuser, H., Sakanoto, T., Martinez-Ruiz, F., 2000b. Temperature and salinity variations of Mediterranean Sea surface waters over the last 16,000 years from records of planktonic stable oxygen isotopes and alkenone unsaturation ratios. Palaeogeogr. Palaeoclimatol. Palaeoecol. 158, 259-280.

Fleming, K., Johnston, P., Zwartz, D., Yokoyama, Y., Lambeck, K., Chappell, J., 1998. Refining the eustatic sea-level curve since the Last Glacial Maximum using far- and intermediate field sites. Earth Planet. Sci. Lett. 163, 327-342.

Foucault, A., Mèlières, F., 2000. Palaeoclimatic cyclicity in central Mediterranean Pliocene sediments: the mineralogical signal. Palaeogeogr. Palaeoclimatol. Palaeoecol. 158, 311323.

Francois, R., Honjo, S., Manganini, S.J., Ravizza, G.E., 1995. Biogenic barium fluxes to the deep sea: Implication for paleoproductivity reconstruction. Glob. Biogeochem. Cycles 9, 289-303.

Freydier, R., Michard, A., De Lange, G., Thomson, J., 2001. $\mathrm{Nd}$ isotopic compositions of Eastern Mediterranean sediments: tracers of the Nile influence during sapropel S1 formation? Mar. Geol. 177, 45-62.

Frost, C.D., O’Nions, R.K., Goldstein, S.L., 1986. Mass bal- ance for $\mathrm{Nd}$ in the Mediterranean Sea. Chem. Geol. 55, 4550.

Gingele, F.X., Zabel, M., Kasten, S., Bonn, W.J., Nürnberg, C.C., 1999. Biogenic barium as a proxy for paleoproductivity: Methods and limitations of application. In: Fischer, G., Wefer, G. (Eds.), Use of Proxies in Paleoceanography: Examples from the South Atlantic. Springer, Berlin, pp. 345 364.

Goldstein, S.L., O’Nions, R.K., Hamilton, P.J., 1984. A Sm$\mathrm{Nd}$ isotopic study of atmospheric dusts and particulates from major river systems. Earth Planet. Sci. Lett. 70, 221236.

Goudie, A.S., Middleton, N.J., 2001. Saharan dust storms: nature and consequences. Earth-Sci. Rev. 56, 179-204.

Grousset, F., Biscaye, P.E., Revel, M., Petit, J.-R., 1992. Antarctic (Dome C) ice-core dust at 18 k.y. B.P.: Isotopic constraints on origins. Earth Planet. Sci. Lett. 111, 175-182.

Grousset, F.E., Biscaye, P.E., Zindler, A., Prospero, J., Chester, R., 1988. Neodymium isotopes as tracers in marine sediments and aerosol: North Atlantic. Earth Planet. Sci. Lett. 87, 367-378.

Grousset, F.E., Minster, J.F., Monaco, A., 1990. Nd isotopes as tracers in water column particles: the western Mediterranean Sea. Mar. Chem. 30, 389-407.

Grousset, F.E., Parra, M., Bory, A., Martinez, P., Bertrand, P., Shiemmield, G., Ellam, R.M., 1998. Saharan wind regimes traced by the $\mathrm{Sr}-\mathrm{Nd}$ isotopic composition of subtropical Atlantic sediments: Last Glacial Maximum vs. today. Quat. Sci. Rev. 17, 395-409.

Guerzoni, S., Guerzoni, S., Chester, R., Dulac, F., Herut, B., Loye-Pilot, M.-D., Measures, C., Migon, C., Molinaroli, E., Moulin, C., Rossini, P., Saydam, C., Soudine, A., Ziveri, P., 1999. The role of atmospheric deposition in the biogeochemistry of the Mediterranean Sea. Prog. Oceanogr. 44, 147190.

Guerzoni, S., Molinaroli, E., Chester, R., 1997. Saharan dust input to the western Mediterranean Sea: depositional patterns, geochemistry and sedimentology implications. DeepSea Res. 44, 631-654.

Henry, F., Jeandel, C., Duprè, B., Minster, J.-F., 1994. Particulate and dissolved $\mathrm{Nd}$ in the western Mediterranean Sea: sources, fate and budget. Mar. Chem. 45, 283-305.

Hilgen, F.J., 1991a. Astronomical calibration of Gauss to Matuyama sapropels in the Mediterranean and implication for the Geomagnetic Polarity Time Scale. Earth Planet. Sci. Lett. 104, 226-244.

Hilgen, F.J., 1991b. Extension of the astronomically calibrated polarity time scale to the Miocene/Pliocene boundary. Earth Planet. Sci. Lett. 107, 349-368.

Hooghiemstra, H., Agwu, C.O.C., 1988. Changes in the vegetation and trade winds in equatorial northeast Africa 140,000-70,000 yr B.P. as deduced from two pollen records. Palaeogeogr. Palaeoclimatol. Palaeoecol. 66, 173-213.

Jacobson, S.B., Wasserburg, G.J., 1980. Sm-Nd isotopic evolution of chondrites. Earth Planet. Sci. Lett. 50, 139-155.

Kidd, R.B., Cita, M.B., Ryan, W.B.F., 1978. Stratigraphy of eastern Mediterranean sapropel sequences recovered during 
DSDP Leg 42A and their paleoenvironmental significance. Init. Rep. DSDP 42, 421-443.

Krom, M.D., Cliff, R.A., Eijsink, L.M., Herut, B., Chester, R., 1999a. The characterisation of Saharan dusts and Nile particulate matter in surface sediments from the Levantine basin using Sr isotopes. Mar. Geol. 155, 319-330.

Krom, M.D., Michard, A., Cliff, R.A., Strohe, K., 1999b. Source of sediment in the Ionian Sea and western Levantine basin of the Eastern Mediterranean during S-1 sapropel times. Mar. Geol. 160, 45-61.

Kullenberg, B., 1952. On the salinity of water contained in marine sediments. Medd. Oceanogr. Inst. Göteborg 21, 138.

Lèzine, A.-M., Casanova, J., 1991. Correlated oceanic and continental records demonstrate past climate and hydrology of North Africa (0-140 ka). Geology 19, 307-310.

Lourens, L.J., Antonarakou, A., Hilgen, F.J., Van Hoof, A.A.M., 1996. Evaluation of the Plio-Pleistocene astronomical timescale. Paleoceanography 11, 391-413.

Loye-Pilot, M.-D., Martin, J.-M., Morelli, J., 1986. Influence of Saharan dust on the rainfall acidity and atmospheric input to the Mediterranean. Nature 321, 427-428.

Martin, J.-M., Elbaz-Poulichet, F., Guieu, C., Loye-Pilot, M.-D., Han, G., 1989. River versus atmospheric input of material to the Mediterranean Sea: an overview. Mar. Chem. 28, 159-182.

Martin, J.-M., Milliman, J.D., 1997. EROS 2000 (European Rivers Ocean System). The western Mediterranean Sea: an introduction. Deep-Sea Res. 44, 521-529.

Martinez, P., Bertrand, P., Shimmield, G.B., Cochrane, K., Jorissen, F.J., Foster, J., Dignan, M., 1999. Upwelling intensity and ocean productivity changes off Cape Blanc (northwest Africa) during the last 70,000 years: geochemical and micropalaeontological evidence. Mar. Geol. 158, 5774.

Martinson, D.G., Pisias, N.G., Hays, J.D., Imbrie, J., Moore, T.C., Shackleton, N.J., 1987. Age dating and the orbital theory of the Ice Age: Development of a high-resolution 0 to 300,000 -year chronostratigraphy. Quat. Res. 27, 129.

Matthewson, A.P., Shimmield, G.B., Kroon, D., Fallick, 1995. A 300 kyr high-resolution aridity record of the North African continent. Paleoceanography 10, 677-692.

McManus, J., Berelson, W., Klinkhammer, G.P., Johnson, K.S., Coale, K.H., Anderson, R.F., Kumar, N., Burdige, D.J., Hammond, D.E., Brumsack, H.J., McCorkle, D.C., Rushdi, A., 1998. Geochemistry of barium in marine sediments: Implications for its use as a paleoproxy. Geochim. Cosmochim. Acta 62, 3453-3473.

Mercone, D., Thomson, J., Croudace, I.W., Siani, G., Paterne, M., Troelstra, S., 2000. Duration of S1, the most recent sapropel in the eastern Mediterranean Sea, as indicated by accelerator mass spectrometry radiocarbon and geochemical evidence. Paleoceanography 15, 336-347.

Molinarli, J.M., 1996. Mineralogical characterisation of Saharan dust with a view to its final destination in Mediterranean sediments. In: Guerzoni, S., Chester, R., (Eds.), The Impact of Desert Dust across the Mediterranean. Kluwer, Dordrecht, pp. 153-162.

Moulin, C., Lambert, C.E., Dilac, F., Dayan, U., 1997. Control of atmospheric export of the dust from North Africa by the North Atlantic Oscillation. Nature 387, 691-694.

Moreno, Targarona, J., Henderiks, J., Canals, M., Freudenthal, T., Meggers, H., 2001. Orbital forcing of dust supply to the North Canary Basin over the last 250 kyr. Quat. Sci. Rev. 20, 1327-1339.

Murat, A., 1999. Pliocene-Pleistocene occurrence of sapropels in the Western Mediterranean Sea and their relation to Eastern Mediterranean sapropels. In: Zahn, R., Comas, M.C., Klaus, A. (Eds.), Proceedings of the Ocean Drilling Program, Scientific Results. Ocean Drilling Project, College station, TX, pp. 519-527.

Olausson, E., 1961. Studies in deep sea cores. Deep Sea Exped. 1947-48 8, 337-391.

Pachur, H.-J., Kröpelin, S., 1989. Wadi Howar: Paleoclimatic evidence from an extinct river system in the southeastern Sahara. Science 237, 298-300.

Paillard, D., Labeyrie, L., Yiou, P., 1996. Macintosh program performs time-series analysis. EOS Trans. AGU 77, 379.

Perissoratis, C., Piper, D.J.W., 1992. Age, regional variation, and shallowest occurrence of S1 sapropel in the northern Aegean Sea. Geo-Mar. Lett. 12, 49-53.

Pokras, E.M., Mix, A.C., 1985. Eolian evidence for spatial variability of Late Quaternary climates in Tropical Africa. Quat. Res. 24, 137-149.

Prospero, J.M., 1996. Saharan dust transport over the Atantic Ocean and Mediterranean: an overview. In: Guerzoni, S., Chester, R. (Eds.), The Impact of Desert Dust across the Mediterranean. Kluwer, Dordrecht, pp. 133-151.

Rea, D.K., 1994. The paleoclimatic record provided by eolian deposition in the deep sea: the geologic history of wind. Rev. Geophys. 32, 159-195.

Rohling, E.J., 1994. Review and new aspects concerning the formation of eastern Mediterranean sapropels. Mar. Geol. $122,1-28$.

Rossignol-Strick, M., 1983. African monsoons, an immediate climate response to orbital insolation. Nature 304, 46-49.

Rossignol-Strick, M., 1985. Mediterranean Quaternary sapropels, an immediate response of the African Monsoon to variation of insolation. Palaeogeogr. Palaeoclimatol. Palaeoecol. 49, 237-263.

Rossignol-Strick, M., Nesteroff, W.D., Olive, P., VergnaudGrazzini, C., 1982. After the deluge: Mediterranean stagnation and sapropel formation. Nature 295, 105-110.

Ruddiman, W.F., 1997. Tropical Atlantic terrigeneous fluxes since 25,000 yrs BP. Mar. Geol. 136, 189-207.

Ryan, W.B.F., 1973. Geodynamic implications of Messinian crisis of salinity. In: Droogers, C.W. (Ed.), Messinian Events in the Mediterranean. North-Holland Publ., Amsterdam, pp. 26-38.

Schenau, S.J., Prins, M.A., De Lange, G.J., Monnin, C., 2001. Barium accumulation in the Arabian Sea: Controls on barite preservation in marine sediments. Geochim. Cosmochim. Acta 65, 1545-1556. 
Stein, R., 1990. Organic carbon/sedimentation rate relationship and its paleoenvironmental significance for marine sediments. Geo-Mar. Lett. 10, 37-46.

Thomson, J., Higgs, N.C., Wilson, T.R.S., Croudace, I.W., De Lange, G.J., Van Santvoort, P.J.M., 1995. Redistribution and geochemical behaviour of redox-sensitive elements around S1, the most recent eastern Mediterranean sapropel. Geochim. Cosmochim. Acta 59, 3487-3501.

Van Os, B.J.H., Lourens, L.J., Hilgen, F.J., de Lange, G.J., Beaufort, L., 1994. The Formation of Pliocene and carbonate cycles in the Mediterranean: Diagenesis, dilution, and productivity. Paleoceanography 9, 601-617.

Van Santvoort, P.J.M., De Lange, G.J., Thomson, J., Cussen, H., Wilson, T.R.S., Krom, M.D., Ströhle, K., 1996. Active post-depositional oxidation of the recent sapropel (S1) in sediments of the eastern Mediterranean Sea. Geochim. Cosmochim. Acta 60, 4007-4024.

Walter, H.J., Hegner, E., Diekamn, B., Kuhn, G., Van der Loeff, M.M.R., 2000. Provenance and transport of terrigenous sediment in the South Atlantic Ocean and their relations to glacial and interglacial cycles: $\mathrm{Nd}$ and $\mathrm{Sr}$ isotopic evidence. Geochim. Cosmochim. Acta 64, 3813-3827.

Wegrzynek, D., Jambers, W., Van Griekn, R., Eisma, D., 1997. Individual particle analysis of Western Mediterranean Sea sediment cores, Rhone suspended matter and Saharan aerosols - Investigation of inputs to the sediments. Mar. Chem. 57, 41-53.
Wehausen, R., Brumsack, H.-J., 2000. Chemical cycles in the Pliocene sapropel-bearing and sapropel-barren eastern Mediterranean sediments. Palaeogeogr. Palaeoclimatol. Palaeoecol. 158, 325-352.

Weldeab, S., Emeis, K.-C., Hemleben, C., Schmiedl, G., Schulz, H., in press. Spatial productivity variations during formation of sapropel S5 and S6 in the Mediterranean Sea: Evidence from Ba concentration. Palaeogeogr. Palaeoclimatol. Palaeoecol.

Weldeab, S., Emeis, K.-C., Hemleben, C., Siebel, W., 2002a. Provenance of lithogenic surface sediments and pathways of riverine suspended matters in the Eastern Mediterranean Sea: Evidence from ${ }^{143} \mathrm{Nd} /{ }^{144} \mathrm{Nd}$ and ${ }^{87} \mathrm{Sr} /{ }^{86} \mathrm{Sr}$ isotope. Chem. Geol. 186, 139-149.

Weldeab, S., Emeis, K.-C., Hemleben, C., Schulz, H., Vennemann, T.W., 2002b. Sr, Nd isotope composition of Late Pleistocene sapropels and non-sapropel sediments from the Eastern Mediterranean Sea: Implications for detrital influx and climatic conditions in the source areas. Geochim. Cosmochim. Acta 66, 3585-3598.

Yarinick, K.M., Murray, R.W., Peterson, L.C., 2000. Climatically sensitive eolian and hemipelagic deposition in the Cariaco Basin, Venezuela, over past 578,000 years: Results from Al/Ti and K/Al. Paleoceanography 15, 210-228.

Zuo, Z., Eisma, D., Gieles, R., Beks, J., 1997. Accumulation rates and sediment deposition in the northwestern Mediterranean. Deep-Sea Res. 44, 597-609. 